IRSH 53 (2008), pp. 293-3 I 2 DOI: I0.10I7/So020859008003453

(C) 2008 Internationaal Instituut voor Sociale Geschiedenis

\title{
SURVEY
}

\section{Picturing the Everyday Life of Limburg Miners: Photographs as a Historical Source*}

\author{
J OERI JANUARI US
}

Summary: Although recent years have seen growing theoretical interest among historians in the use of visual material, researchers continue to neglect the importance of photographs as source material. This is particularly striking since, now that iconographic material is becoming more widely available and archival institutions are beginning to place greater emphasis on visual material as use of the simple camera becomes more widespread, photographs often provide the only source of essential information for study. They illuminate the concept of the everyday, which in turn casts light on the significance of consumer goods, domestic comfort, the aspirations of men, women, and children, in short the banality of everyday life which echoed their mentalities and how they viewed the world.

In recent years, there has been growing interest in photographs as a source for historians, and fertile theoretical steps have already been taken to incorporate such iconographic material into the historical métier and to


and Johan Huizinga, both cultural historians, used paintings as a source in

* This article is a revised version of a piece published earlier in the journal, Brood en Rozen. See Joeri Januarius, "Foto's met autoriteit. Alledaagsheid in het leven van Limburgse mijnwerkers in de jaren 50", Brood en Rozen, I 2 (2007), pp. 5-25. I am indebted to Paule Verbruggen (AMSABArchief en Museum van de Socialistische Arbeidersbeweging in Ghent), Filip Delarbre (Archief Vlaams Mijnmuseum in Beringen), and Jan Kohlbacher (Stichting Eisdens Erfgoed in Eisden) for their assistance. I would also like to thank Prof. Peter Scholliers (Vrije Universiteit Brussels), Prof. Patricia Van den Eeckhout (Vrije Universiteit Brussels), Bart Delbroek (Vrije Universiteit Brussels), Nelleke Teughels (Vrije Universiteit Brussels), an anonymous reviewer for this journal, and Martine Maris for their useful criticisms and remarks on earlier versions of the manuscript. The translation is by Chris Gordon.

I. See, for example, Peter Burke, Eyewitnessing: The Uses of Images as Historical Evidence (New York, 200I); Fernando Coronil, "Seeing History", Hispanic American Historical Review, 84 (2004), pp. I-4; Martyn Jolly, "Fake Photographs: Making Truths in Photography" (unpublished Ph.D. thesis, University of Sydney, 2003). 
their work on the Renaissance and Middle Ages respectively. Philippe Ariès, in his history of childhood, and more recently, Raffaella Sarti in her history of family and material living in early modern Europe frequently use prints and paintings. Nonetheless, despite that, there is a striking lack of historical research utilizing visual material, which is the more remarkable since such material is becoming more readily available with the greater use of cameras.

Ironically, the very quantity of visual material now available seems to reduce the perception of the value and usefulness of photographs, for although carefully selected pictures are often used to enliven the presentation of academic research, little is usually done with the photographs themselves, which remain mostly illustrative. They are used therefore not to clarify some point but to illuminate. Other social disciplines are more advanced in that respect. Indeed, so far, photographs have been the exclusive preserve mainly of philosophers, art historians, and anthropologists, for whom both the metaphysical significance and the aesthetic value of visual material is of central importance. In recent years, anthropologists and art historians have endeavoured to promote crossfertilization with historians in relation to the use of photographs. ${ }^{2}$

Photographs can be an essential source of information for historians. For example, visual material plays an important role in the study of material culture and the everyday; photographs and material relics are often the only sources available for studies of working-class interiors or of objects in use in middle-class homes during the twentieth century. Written sources such as diaries and inventories, as well as oral history, can enrich such studies, but if they do not exist, have not been preserved, or are inaccessible, photographs are often the historian's sole recourse.

The present article points to the photograph as a source for historians and considers how visual material can contribute to historical research, though it goes without saying that photographs should not be used uncritically. How can photographs be treated as a historical source, and what information can be gleaned from them by the historian? In answering

2. Sarah Pink, Doing Visual Ethnography (London, 2007); Elizabeth Edwards, "Photography and the Performance of Histories", in Peter Hamilton (ed.), Visual Research Methods, 4 vols (London, 2006), III, pp. 239-258. Recently, historians and art historians, especially in the Netherlands, have begun to pay particular attention to the use of photographs as a historical source. See, for example, Marga Altena, Visuele strategieën. Foto's en films van fabrieksarbeidsters in Nederland I890-1919 (Amsterdam, 2003), and Ellen Tops, Foto's met gezag. Een semiotisch perspectief op priesterbeelden 1930-1990 (Nijmegen, 200I). See too Alain Dewerpe, "Miroirs d'usines: photographie industrielle et organisation du travail à l'Ansaldo", Annales, 42 (1987), pp. I079-III4; Klaus Tenfelde, Bilder von Krupp. Fotografie und Geschichte im Industriezeitalter (Munich, 2000). For a good survey of how photographs are used by various social disciplines see Hamilton, Visual Research Methods, and Liz Wells (ed.), The Photography Reader (London, 2003). 
these questions, we will try to help any historians wanting to use photographs as a source to escape from a methodological impasse.

As an example, we shall "read" two photographs illustrating the lives of mining families in Belgian Limburg in the I950s. In general terms, we already know a great deal about the everyday life of miners themselves, ${ }^{3}$ but we are often left to guess about the roles of consumer goods, domestic comfort, the aspirations of men, women, and children, in short about the banality of everyday life which reflected their mentalities and how they viewed the world. Beyond photographs, relics, and oral testimony, there is little material that can illuminate material life in Limburg's garden cities, which were specially designed in the early twentieth century in this thinly populated and primarily agrarian province - a province that had not previously experienced heavily industrialized sectors such as mining to any great extent.

Our reading of the two selected photographs serves a dual purpose. First, photographs of interiors enable us literally to peer into the lives of these mining families. The exploration of everyday life, as de Certeau has termed it, contributes to the study of the emergence and development of consumer society. Second, this visual material can illuminate the culturalizing approach taken towards the history of consumption, in which consumption is viewed as a potential means to differentiate oneself from the outside world. By considering the relationship between members of a certain family and their pots, pans, tables, and chairs, and how a particular interior was furnished, one can attribute a meaning to those ordinary objects and study the construction of the identity and aspirations of those particular groups of workers. ${ }^{4}$

Clearly, one cannot say all there is to know about the everyday life and material culture of the miners on the basis of just two photographs; 5 they are unlikely to be representative, but then that is not the purpose of this

3. Tine De Rijck and Griet Van Meulder, De ereburgers. Een sociale geschiedenis van de Limburgse mijnwerkers (Berchem, 2000), pp. 204-403; Ginette Kurgan-Van Hentenrijk and Jean Puissant, "Industrial Relations in the Belgian Coal Industry since the end of the Nineteenth Century", in Gerald Feldman and Klaus Tenfelde (eds), Workers, Owners and Politics in Coal Mining: An International Comparison of Industrial Relations (New York, 1990), pp. 203-270; John Benson, British Coalminers in the Nineteenth Century: A Social History (London, 1989). 4. Paul Glennie, "Consumption within Historical Studies", in Daniel Miller (ed.), Acknowledging Consumption: A Review of New Studies (London, 1995), pp. 164-203, esp. pp. I64 and 178-179. See also John Brewer and Frank Trentmann (eds), Consuming Cultures, Global Perspectives: Historical Trajectories, Transnational Exchanges (Oxford, 2006); Arnd Schneider, "On 'Appropriation'. A Critical Reappraisal of the Concept and its Application in Global Art Practices”, Social Anthropology, i I (2003), pp. 2 I 5-229.

5. Annemarie Money, "Material Culture and the Living Room: The Appropriation and Use of Goods in Everyday Life", Journal of Consumer Culture, 7 (2007), pp. 355-377, 355-357; Justine Lloyd and Lesley Johnson, "Dream Stuff: The Postwar Home and the Australian Housewife, 1940-60", Environment and Planning D: Society and Space, 22 (2004), pp. 25 I-272, esp. pp. $25 \mathrm{I}-253$. 
article. Our reading of these photographs will still provide valuable insights because we are looking at which objects are displayed in a space, at the relationship between individuals and that space, and at the significance attributed to specific spaces. Before discussing this, however, we shall consider the nature of photography as a medium, which brings us to the world of art historians and philosophers. This is necessary not only to understand the value to historians of this source, but also to explore analytical methods.

\section{ART, REALISM, OR SOURCE}

Photography has a fairly recent history. The key point in its development was I 839, the year in which the photographic process was perfected more or less simultaneously in France and England. In France, Nicéphore Niépce (I765-I833) and, after his death, Louis-Jacques Mandé Daguerre (I787-I85I) developed a way of fixing images onto silver-coated copper plates using lithography and heliography. In England, at the same time, William Henry Fox Talbot (I800-I877) was trying to fix images onto light-sensitive paper. Since then, scientists have experimented to improve the quality of photographic images and the process by which they are made, efforts which have culminated in the digital photography of today, by which the traditional chemical process linked to optical methods has been rendered redundant. ${ }^{6}$

The link between the new medium and existing art forms such as painting was ambiguous. In the nineteenth century there was a strong belief in photography as a reflection of reality. Often objectivity, realism, and photographs were referred to in the same breath. A photograph of a building was regarded as a perfectly reproduced image of that building. However, that accuracy was as much an obstacle to artistic creativity, which soon ensured a wave of criticism insisting that this new medium was not an art form but merely an act of reproduction. ${ }^{7}$

Within general photograph theory and photograph criticism, the question regarding the relationship between the photograph and reality continues to be controversial, especially among philosophers of art and art scholars. At one end of the theoretical spectrum are the realists, who regard photography as providing a basis for reality. One representative of this view is Susan Sontag, whose collection of essays, On Photography, published in 1977 regards photography as offering a form of evidence that something exists. When a photograph is taken, the photographer makes what approximates to a perfect image of that situation. Photographs

6. Johan Swinnen, De lichte kamer. De onverborgen fotografie (Antwerp, 2005), pp. 30-3 I.

7. Liz Wells and D. Price, "Thinking about Photography", in Liz Wells (ed.), Photography:

Critical Introduction (London, 1997), pp. 20-24. 
cannot mislead the viewer, and if they do then the intermediary, in this case the photographer, will have failed to capture a proper image. At the other end of the spectrum are the symbolists, who, in reaction to the realists, regard a photograph as a symbolic image. Nihilists, in turn, claim that photographs neither illustrate reality nor convey meaning. The American art critic, Mary Price, argues that in itself a photograph does not have an intrinsic meaning, but its significance depends on how it is used. In a particular context a meaning will emerge, and the subject to which a photograph refers is thus but one of the factors playing a role in the construction of that photograph's meaning. ${ }^{8}$

This debate has prompted a number of questions regarding how photographs should be interpreted and the types of photograph that can be distinguished. The basic taxonomy in use during the earliest days of photography reflected the distinction between the purist and pictorialist. The first championed a pure, authentic photography that dissociated itself from painting, while the pictorialists were more inclined to regard photography as an art form and exploited every means to improve the artistic quality of a photograph. This taxonomy was later employed by others too, including John Szarkowski, Director of Photography at New York's Museum of Modern Art from 1962 to I99I. In 1957 the photographer Minor White developed a very influential theoretical model for interpreting photographs which distinguished different kinds of photograph. Documentary photographs or images bestow on their content the greatest significance, while pictorial photographs are more personal, in the sense that they reflect the photographer's own vision. Informal or informational photography refers to "scientific" photography such as aerial photography and architectural photography. ${ }^{9}$

This article does not intend to contribute any new dimension to the debate on contemporary photograph theory and criticism. The question of whether photography should be regarded as an art form is not of immediate concern to historians, nor, despite their intrinsic interest, is it of prime importance to consider questions concerning the compositional value and artistic structure of a photograph. What is important for historians is to realize that photographs offer important source material, certainly about subjects such as the material culture of labourers, where it is often difficult or impossible to use traditional historical sources. One must, of course, appreciate the context in which a photograph was taken and used, and take note of the format employed, which are questions historians will likewise ask of any other historical sources in their source criticism. Further, photographs can undoubtedly be regarded as a source

8. Johan Swinnen, De paradox van de fotografie. Een kritische geschiedenis (Antwerp, I992), pp. 209-2 Io; Wells and Price, "Thinking about Photography", pp. 37-42.

9. Swinnen, De lichte kamer, pp. 28-29. 
every bit as important as, say, written texts. Given an adequate methodology and the instruments of historical criticism, the historian can set to work with photographs quite confidently.

\section{READING A PHOTOGRAPH: ICONOGRAPHY}

In other disciplines, too, scholars have debated how one should approach iconographic material. Before suggesting a possible historical method for reading a photograph, and the questions that can be asked of such visual material, it is worth considering what we can learn from iconography and semiotics.

Iconography as a research field is a branch of art history and was developed in the I920s. Within iconography, various schools of thought were prominent at the beginning of the twentieth century, and Emile Mâle was one of the leading lights of the French tradition, which attached great importance to textual sources. The Princeton School, founded by Charles Rufus Morey, placed more emphasis on the traditions of visual representation, and Germany saw the emergence of the well-known Warburg School, led by Aby Warburg. The degree of scholarly diversity was considerable, but it was largely the Warburg School, and more especially the ideas of Erwin Panofsky, which was to be the most influential. ${ }^{ }{ }^{\circ}$

The underlying principle of iconography is that all works of art contain an important intellectual component; that concealed within it is a particular philosophy or theology. One of the most successful definitions of iconography is the following: "[it] applies to the descriptive and the classificatory study of images with the aim of understanding the direct or indirect meaning of the subject matter represented". II This approach contrasts radically with formal analyses of paintings, which have emphasized composition or colour. ${ }^{12}$ "Iconography is that branch of the history of art which concerns itself with the subject matter or meaning of works of art, as opposed to their form", as Panofsky wrote in his classic work (first published in 1939) detailing the principles of iconography. ${ }^{13}$

Iconographic analysis comprises three strata. First, there is the primary: the pre-iconographical interpretation by which the painting's basic forms are perceived. The natural meaning of an object is described, as are events (trees, houses, meals, processions, for example), and the descriptions draw on one's knowledge and understanding of, in this case, the material culture.

ı. Brendan Cassidy, "Introduction: Iconography, Texts, and Audiences", in idem (ed.), Iconography at the Crossroads (Princeton, NJ, 1993), pp. 3-15, 5.

I I. Ibid., p. 3 .

I2. Burke, Eyewitnessing, pp. 34-35.

13. Erwin Panofsky, Studies in Iconology: Humanistic Themes in the Art of the Renaissance (London, 1972), p. 3. 
The secondary stratum consists in iconographic analysis in the strict sense, by which a conventional meaning is attributed to the objects discussed. Specific themes and concepts are linked to these art forms, so that a painting of a group of figures seated around a table can be said to represent the Last Supper or an image of a man standing in a river bearing a young child on his shoulders can be understood to represent St Christopher. Such analysis draws on knowledge of available art-historical literature and an understanding of everyday themes and concepts. That leaves the third stratum: iconographic analysis is arrived at, or an iconographic synthesis in which an attempt is made to understand the intrinsic meaning and content of a certain work, in other words "those underlying principles which reveal the basic attitude of a nation, a period, a class, a religious or philosophical persuasion". ${ }^{14}$ Panofsky argued that this fundamental analysis, based on symbolic interpretation, is the product of the intuition and the worldviews of the author in question.

An important prerequisite in iconography is that researchers have a certain expertise in a particular period before they can properly apply the method. They must be aware of the relationship between the image and the artist's contemporaries, and so they must be able to recognize the meaning of objects and landscapes. Further, an eye for detail in identifying not just the artists concerned but cultural meanings is necessary, as is a great deal of additional research work. Iconographers often interpret a work of art by comparing them with other works and by identifying and using written sources such as inscriptions. ${ }^{\text {is }}$

Iconographers themselves take a critical view of the various analytical stages, especially in interpreting visual material on the basis of extant texts. The relationship between the use of texts as an explanation and visual material as a source is often distorted, in the sense that the visual material is not always regarded as paramount. Texts do serve as an explanatory factor in iconography, but they should be supplemented by as wide a range of references as possible in order to help the historian explain. The purpose of such criticism, the subject of a colloquium on iconography in 1990, was to give visual material once again a prominent place in research, without textual sources being abandoned. The message for the historian is clear: "they must also learn when to let go of their texts and approach images on their own terms and on terms that would have been familiar to their creators". ${ }^{16}$

There is also the important criticism that some stages in the analytical framework, interpretation for example, are markedly intuitive in character. Moreover, considerable attention is paid to the inherent meaning of the

I4. Ibid., p. 7 .

I5. Burke, Eyewitnessing, pp. 38-40.

I6. Cassidy, "Introduction: Iconography, Texts, and Audiences", p. Iо. 
work of art itself without examining its possible social significance and the context in which it originated, two aspects providing relevant information when analysing visual material. The question of who determines the meaning inevitably arises if one considers the work of art by itself, since it is very possible that different interpreters will ascribe different meanings to the same work. ${ }^{17}$

In his analysis of the use of visual material such as photographs, Peter Burke examines the value to the historian of iconography, arguing that its basic principles can certainly be of use, but that the historian should go beyond that and ask critical questions of the photograph as a source and of the method whereby visual material can be analysed. It is indeed true that iconographers are concerned solely with the artistic aspects of works of art and visual material, while historians see the photograph not as a work of art but as a source of information. ${ }^{18}$

\section{THE PHOTOGRAPH AS A SYSTEM OF SIGNS AND SYMBOLS: SEMIOTICS}

Those historians who, in the past, have considered the use of photographs have advocated semiotics as the most suitable method for reading photographs as a source. ${ }^{19}$ Images can speak or communicate, and semiotics endeavours to explain that communication. A photograph always depicts something; it always refers to something that semioticians term a "sign". A photograph of a kitchen is not a photograph of the kitchen itself, but a depiction of that kitchen at a certain point in time; the photograph is thus a reference to the kitchen. As in iconography, here too there are several stages in the analytical process. The first is denotation, which can be compared with the pre-iconographical phase. A photograph comprises a number of elements that each must be named; each component of the image must be discussed, regardless of how small or insignificant it might appear at first sight.

The next stage is important in interpreting a photograph, because it involves the ascription of meaning to all these components. The signs are connotated, and thus the photograph as a whole acquires a meaning as a result of the mutual relationship between all its components. ${ }^{20}$ The internal structure of a photograph is thereby exposed, giving rise to several immediate consequences. By focusing on isolated signs which, given a certain relationship, constitute the structure of a photograph, semiotics

17. See the seminal work by John Berger, Ways of Seeing (London, 1972).

I8. Burke, Eyewitnessing, p. 42.

19. Ibid., p. I7; Hendrik Ollivier, Met licht geschreven. Foto's uit een eeuw dagelijks leven (Ghent, I994), p. I 8; Jean-Louis Jadoulle et al. (eds), L'Histoire au prisme de l'image. L'Historien et l'image fixe (Louvain-la-Neuve, 2002), pp. i 5-25.

20. Swinnen, De paradox van de fotografie, pp. 196-i 97. 
places the emphasis much more on contradictions or on how certain signs interrelate. Burke gives the example of a photograph of a beautiful woman. Next to the woman is a car, which ensures that both the sign "woman" and the sign "car" take on another meaning. If we juxtapose the same woman with a tractor, in the kitchen, or in the garden, the woman, and thus the image as a whole, takes on a different meaning each time. Furthermore, this approach strongly accentuates the elements that are present and those that are absent. What is included in the photograph, and what is not? What is portrayed, and what is not? That is an extremely important point and should be emphasized. It is a corollary of the silences that punctuate speech and that often reveal more than what is actually being said. ${ }^{21}$

The power of this general semiotic approach lies in its comprehensive analysis of an image. Detail by detail, all the layers of a photograph are completely dissected and discussed, and the very relationship between the actors in the image is treated as a key element. As is the case with iconography though, a semiotic reading of a photograph can be criticized. In semiotics, the basic approach takes little account of the contextual information that is important for reading the photograph. Moreover, semiotics ensures a rigid approach to photographs, seeing them as a conscious system of signs that have to be deciphered. Burke even uses the term "reductionist": semiotics effectively leaves little scope for variation. "The weakness of the structuralist approach is the propensity to assume that images have ' $a$ ' meaning, that there are no ambiguities, that the puzzle has a single solution, that there is one code to be broken", he writes, with justification. ${ }^{22} \mathrm{He}$ also points out that the difference in approach between the iconographic and the semiotic is not essentially all that great; both methods are characterized by description and analysis, they differ only in their approach.

\section{A SINGLE METHODOLOGY?}

In his book, Peter Burke concludes that it is difficult to advance an unambiguous and universal technique to analyse systematically such visual images as photographs, but he does offer historians some initial thoughts. Images, he argues, are indicators of a particular world; nor should one ignore the role of the photographers who took such photographs for a specific purpose. The context already referred to, Burke goes on to say, is necessary to place photographs correctly, and he advocates a rigorous analysis of visual material: details are important, but the things not illustrated are of interest too. Just as historians read between the lines when 
analysing texts, so must they look between the lines when studying a photograph. ${ }^{23}$

As Burke argues, it is advisable to adopt a cautious approach in proposing a comprehensive and practicable method for historians. Before one can even begin to analyse a particular photograph, a historian needs to ask a great many questions of the source. Questions about the photographer's identity, the raison d'être of the image and its dating are fundamental to photograph analysis. One also needs to carry out a technical analysis of the photograph (material, technique, whether it is an original, etc.) and to ask questions regarding its authenticity since these too will yield relevant information. Often, it is an arduous endeavour because many photograph collections either ignore those aspects or regard them as irrelevant. Then, one can embark on the actual analysis of the photograph.

Both in iconography and semiotics the image is discussed in terms of layers or levels: first an analysis of what one sees in order then to ascribe a meaning. This dual method can most fruitfully be applied by discussing in detail the various factors relating to the photograph, however minor they might appear. This methodology is based on the ideas of Roland Barthes (spectator, spectrum, and operator). ${ }^{24}$

The analysis begins with the photographer. We have to ask where he is standing and what he includes in or excludes from the image. Was the photograph commissioned, and if so by whom? If not, why was the photograph taken? That brings us to the various actors portrayed in the image. Who are they? What are they doing? How do they relate to the camera? How do they relate to the objects they might, or might not, be touching or to the other people captured in the image? How are they dressed, and how is their hair arranged? A third factor is the landscape and the setting in which the actors are located. Where is that? What does the setting look like? What factors dominate the landscape? What is included and, more importantly, what is not, and why? This is an exhaustive description of the image, which, as with semiotics, posits relationships between objects, actors, and the space into which the image is incorporated.

A second stage is that of connotation, the ascription of a meaning to all those factors, without working one-sidedly and without losing sight of the context. The fact that a labourer might be wearing his best clothes (or not) for the photographer has a meaning within the context of that period and that group, even if the photograph is posed. Nor should we lose sight of the fact that often the taking of a photograph is preceded by certain interventions, which ensure that reality is not represented "faithfully". The historian must reflect critically on those images, and in some cases further

24. Roland Barthes, Camera Lucida: Reflections on Photography (New York, 198 I), p. 9. 
information is needed to amplify an image if one is to avoid being left with more questions than answers.

Contextual information must be understood in the broad sense of the term: political, cultural, social, and economic factors must all be emphasized if necessary. By saying one should not take too one-sided an approach we mean that the historian must not seize uncritically upon a particular meaning yielded by those three levels, a warning which brings us to a criticism we can level at this method. Questions will certainly be asked regarding objectivity in the approach to the photographic material, but then questions must always be asked regarding the objectivity of research, even in relation to written sources since there too historians interpret, based on knowledge they have acquired and on the conceptual frameworks they apply. Moreover, often the source photograph will be reproduced, allowing readers to analyse and judge for themselves.

\section{LIVING IN A GARDEN CITY: GLIMPSING THE EVERYDAY}

In the following section, we put the theory outlined above into practice by reading two photographs relating to the material culture and everyday life of Limburg miners. We are conscious that, as a starting point, these two photographs provide only a narrow basis, but by combining theory and practice a number of research questions and fields can be advanced.

The two photographs - randomly selected here - are of interiors and date from the i950s. They both give a view of the dining room in the house of a mining family, but the houses are situated in different garden cities. By carefully reading these photographs we can try to learn more about how miners' families organized and decorated their homes, what materials and models they used, to which places they assigned items and objects, and the relationship between the individuals and that space and those objects. Answers to these direct questions can give us an indication of how miners made these homes their own and thus of how they saw and projected themselves as a working-class group and what their aspirations were.

A study of the material culture ${ }^{25}$ and everyday life of miners based on photographs cannot ignore the contextual information that casts light on housing and the architectural features that characterized dwellings in the garden cities. Particularly relevant are the specific employment strategies used by the mine owners to attract labourers to that thinly populated and mostly agricultural region. Other research has shown that housing in the Limburg mining region was a well-considered strategy on the part of mine owners and the Catholic movement. In Limburg, coal was discovered later

25. The term refers to the life cycle of an object and the way it evolves as a result of its relationship to its environment and contact with people. See Judy Attfield, Wild Things: The Material Culture of Everyday Life (Oxford, 2000), p. 3 . 
than in the Walloon basin, for it was not until I $90 \mathrm{I}$ that test drillings by the geologist André Dumont in the village of As yielded bituminous coal. By the time a number of mining companies had set themselves up along the axis running between the municipalities of Beringen and Eisden to develop their activities, the mine owners had learned from the situation in Wallonia. Poor housing and living conditions there were a cause of social unrest and formed a fertile ground for the growth of the socialist movement, which was something the mine owners and the influential Catholic movement wanted to avoid at all costs in Limburg. Moreover, by providing good housing the mine owners also had a means to attract workers. ${ }^{26}$

In opting for the concept of the garden city, the mine owners and the Catholic movement were responding to an architectural idea that originated in England, where in his To-Morrow: A Peaceful Path to Real Reform (1898) Ebenezer Howard promulgated the idea of the garden city. In Belgium his ideas were developed by Jean Bary, an advocate of the idea of the garden city, which he regarded quite literally as a neighbourhood in a garden environment rich in green space, rather than the specific residential model Howard advocated for England. Both the method proposed to finance the garden city (as an association of residents and shareholders) and the fact that a garden city was required to operate financially and economically independently were ideas that never really took hold in Belgium. But the concept of a garden city remained interesting: labourers could live in a green neighbourhood amid the tranquillity for which the countryside was known. The residents of a garden city felt they were living in a neighbourhood of an urban agglomeration. Furthermore, the garden city was characterized by a particular type of housing, with a preference for single-family dwellings built in a cottage-style, which allowed sufficient space for a modest front and back garden and ensured a sense of security. Those gardens also ensured that in their spare time residents could engage in relaxing healthy pursuits, which also benefited social contentment. In addition to purely hygienic considerations, moral convictions too played an important role in the rise of the garden city. ${ }^{27}$

26. De Rijck and Van Meulder, De ereburgers, pp. 204-205; Mieke Van Haegendoren and Bart Pluymers, "Belgisch-Limburgse mijnwerkers in de jaren twintig. Willige slachtoffers van het kapitaal of een 'blauwe-maandag compagnie'?", Tijdschrift voor sociale geschiedenis, 24 (1998), pp. 31-55, 53-54; Erik Nijhoff, "Snail and Snail Shell: Industrial Heritage and the Reconstruction of a Lost World", in David Barker and David Cranstone (eds), The Archaeology of Industrialization (Leeds, 2004), pp. 299-3 1 2, 300-301.

27. Amy Ogata, Art Nowveau and the Social Vision of Modern Living: Belgian Artists in a European Context (Cambridge, 200I), pp. I20-I29; Marcel Smets, De ontwikkeling van de tuinwijkgedachte in België. Een overzicht van de Belgische volkswoningbouw 1830-1930 (Brussels, I977), pp. 78-80; Mark Pittaway, "Stalinism, Working-Class Housing and Individual Autonomy: The Encouragement of Private House Building in Hungary's Mining Areas, 1950- 
Both the government and the municipalities, as well as architects, monitored the siting of the new homes in Limburg very closely; surveys were carried out and regulations enacted. In its model regulations of 1906 the provincial government required municipal supervision of the overall draft plans, which led to wide streets having to have sewers and the fourroom single-family dwellings having to be built on large plots. From i 908, the first simple dwellings were erected, though it quickly became apparent that they were inadequate. It was not until after World War I that the first real attempts were made to build the typical garden cities. ${ }^{28}$

The first photograph shows the Schrijvers-Derwaa family, who during the I950s lived at I9 Sauvestrelaan in Beringen, a municipality in which the first simple dwellings were built as early as 1908 (Figure I). ${ }^{29}$ The photograph was commissioned by the mining company and is taken from a film about the life and work of the miners being made at the time by the Beringen mine. The purpose of the film was clear: Beringen's in-house magazine Onder en Boven included the following announcement: "that it was desirable to produce a new film to portray work as it is today in the mines, both above and below ground. The new film is entitled Beringen 1960. It is almost finished." ${ }^{\circ}$ So it was a promotional-recruitment film, a fact we need to bear in mind when reading the photograph, which itself is just a still from the film. This new film was necessary because, as we read:

[...] given that the workers appear to value the mine less, it is very important to demonstrate to the public that a modern company such as Beringen ensures not only excellent health and safety conditions at work, it also offers them a welcoming environment which has so far not failed to attract the working masses to Beringen. ${ }^{3}$

Unlike the first photograph, the second, from the archives of the Stichting Eisdens Erfgoed [Eisden Heritage Foundation], was taken by a member of the miner's own family, in this case a Polish family, according to the archive description (Figure 2). The photograph shows Mania Juwa, the wife of Tadeusz Swidzinski, a miner whose parents emigrated to Belgium in the 1920 and settled in the mining municipality of Eisden after

4", in Susan E. Reid and David Crowley (eds), Style and Socialism: Modernity and Material Culture in Post-War Eastern Europe (Oxford, 2000), pp. 49-64, 49-5 I.

28. De Rijck and Van Meulder, De ereburgers, pp. 204-207; Veerle Jacobs, "De sociale huisvestingsproblematiek van de Limburgse steenkoolmijnen", in Daniël Coninckx (ed.), Acta van het colloquium Limburg 1945-1992 (Diepenbeek, 1994), pp. I47-I48; Bart Delbroek, De koolputters. Geschiedenis van de Limburgse mijnwerkers (Zwolle, 2005-2007), pp. I47-I54, I I4-I I 5; Patricia Van den Eeckhout, "Belgium", in Colin Pooley (ed.), Housing Strategies in Europe, I880-1930 (Leicester, I992), pp. 190-220.

29. See the publication in which the photograph was published: Onder en Boven, I3 (1960), p. 8.

30. Onder en Boven, i I (1960), p. 8.

31. Quoted in Onder en Boven, I3 (1962), p. I9. 


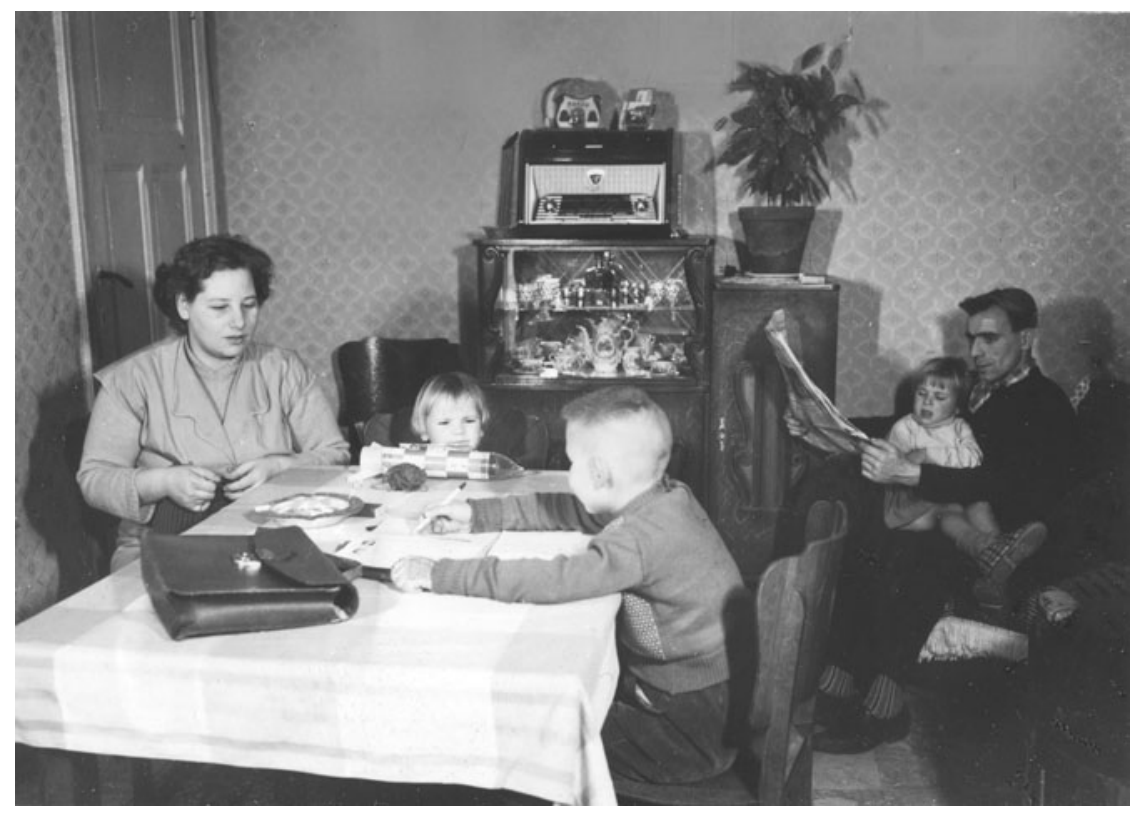

Figure I. Dining room in a miner's house in Beringen, second half of the I950s.

Copyright Archief Vlaams Mijnmuseum (AVM), audiovisual collection, no. 5277, Onder en Boven, 44 (1960), p. 8. Used with permission.

World War II. In his spare time Tadeusz was a photographer; Mania occupied herself with bijouterie. ${ }^{32}$

Before exploring what these photographs can tell us, it is important to analyse the images carefully. We do not know who took the first photograph, but we do know that it is part of the promotional film, Beringen 1960. The photograph shows us the dining room in which the miner's family is happily passing time together. The image is taken not looking towards the centre of the room, but directed towards a corner, where a light-coloured door can be seen. The table and the furniture set against the wall occupy a central position in the photograph. The other walls, the one behind the armchair in which the man is sitting for example, cannot be seen. The photograph succeeds in portraying the family as a close-knit unit. At the table, which is covered with a light-coloured tablecloth, sit three actors: a woman with short curly hair and two young children. A young boy with short hair is reading a book; a younger child, perhaps a girl, is playing at the head of the table and seems to be looking nonchalantly at her elder brother or at the camera, slightly distracted from

32. See the description of the photograph in Archief Stichting Eisdens Erfgoed, Poolse bewoners cité collection. 
what she was doing. The woman, presumably the children's mother, is knitting. Prominently visible on the table is a satchel; at first sight it appears to have been thrown there quite casually.

The second part of the analysis brings us to the two items of furniture at the centre of the photograph, which draw our attention due to the plant and to the wireless set on the cabinet. Both objects - plant and wireless set - deserve our attention and will be discussed below. The cabinet on which the wireless set stands contains various knick-knacks and the best tea service (used only on special occasions) and is closed at the bottom. The piece of furniture on which the plant has been placed is perhaps a tall stand or cupboard. On the wireless set itself there are two objects, presumably decorative, though we cannot be sure what they are. The wireless set is not plugged in; we can see the plug to the left of the plant. Behind the plant especially we can see a distinct shadow, which indicates that the room was lit while filming took place. Perhaps there was a window somewhere through which daylight entered. The third part of the photograph brings us to the neatly dressed man sitting quietly, holding a newspaper, with a small child, probably a girl, on his lap. We see something white protruding - perhaps the man is sitting on a cushion or a blanket.

At the level of the surroundings, or what we should call the context, we notice that little if any attempt has been made to decorate the wall, although probably it has been wallpapered: we can see a pattern comprising small motifs. It is a living space which is both a place to relax (wireless set and armchair) and a place to eat (table and chairs).

The photograph can be interpreted on two levels. First, as a eulogy to family values. We may assume that the family is complete: the mother is looking after the two eldest children while the father, sitting in his armchair quietly reading his newspaper, is, in his own way, occupied with the youngest child. He seems to be sitting very comfortably in his chair, while his wife is sitting at the table, on a wooden chair, a distinction that serves to emphasize the traditional hierarchy in the family between mother and father. Furthermore, this room seems to have just the one armchair (obviously for the father). The children in the photograph occupy themselves quietly and peacefully. The eldest is reading a book; he is probably doing his homework and the satchel lying on the table is his. The young child at the table seems to be playing, the mother is knitting, and the father reading his newspaper. So various activities were being carried out simultaneously by the members of the family. But the main message suggested in this image is that the father, in this case a miner, can depend on his wife and children to provide him with a place to rest after a hard day's work at the mine, and so mining offers considerable benefits and is by no means incompatible with a healthy family life.

Second, we can interpret the photograph in terms of the family's lifestyle and the furnishing of the interior. The wireless set occupies a prominent 
position in the photograph. It had become a feature of the miners' milieu as early as the I930s, though here it comes across as being particularly important. The cabinet, containing the best tea service, and the stand or cupboard for the plant (is it artificial or real?) would appear to be made from robust material and also point to the need to decorate the space. The best tea service is in the dining room and is given a place of prominence, manifesting a degree of status. The plant suggests domesticity, permanence, and comfort. 33 That sense of robustness can be seen at the table too, where the chairs in particular convey an impression of sturdiness. One significant observation is that only three chairs are actually visible in the photograph, suggesting that it was not possible for the whole family to eat at the table at the same time, although of course the chairs might have been rearranged for the benefit of the picture. A tablecloth decorates the table, an indication of cleanliness, as is the external appearance of the actors in the photograph: short hair, neat clothes. In short, a respectable standard of living to which a labourer could reasonably aspire when he began to work for the mine.

The staging of the photograph and the image that the mining company wanted to portray are clear. One could of course ask to what extent the family actually lived like that or in that space, which immediately raises the question of how truthful the image is. Nonetheless, the photograph does tell us something about which objects were placed in the dining room (at the level thus of material culture) and about the significance that can be ascribed to them. One notices for example that, as we have already remarked, the wireless set, indicating a form of leisure, occupies a central position in the photograph. Some objects are conspicuous by their absence: there are no paintings on the wall, nor any other decorative objects, such as a crucifix, a clock, or photograph frames. Perhaps these were hung in one of the other rooms, or perhaps the photographer removed them. Or perhaps this family simply did not have them. But a choice of objects has been made, and that says a great deal about the image the film wanted to convey of the ideal miner's family.

If we now compare this photograph with the one taken by a miner's own family, we can repeat this process of discussing and interpreting the various levels that make up the image. In the case of the second photograph, we have little background information relating to its purpose. Here, too, the photographer has focused on a particular space - the dining room. The photograph is composed in such a way that the woman occupies a central position. Together with the large framed photograph on

33. The presence of plants and flowers was a commonplace phenomenon in the dwellings of Catholic workers' families in the postwar period. They added a personal touch to the interior. See Fredie Flore, "Promoting Catholic Family Values and Modern Domesticity in Postwar Belgium", in Hilde Heynen and Gülsüm Baydar (eds), Negotiating Domesticity: Spatial Productions of Gender in Modern Architecture (London, 2005), pp. 83-102, 93. 


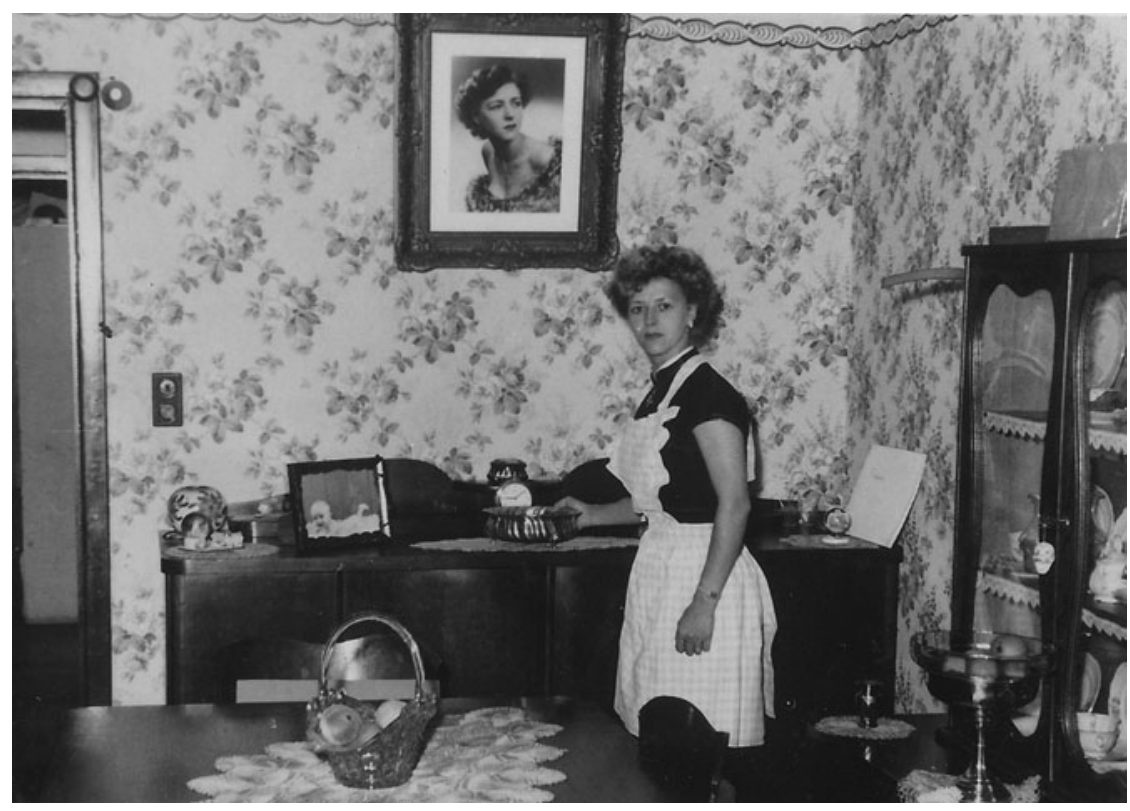

Figure 2. Photograph taken in a miner's house in the garden city of Eisden, I950s. Copyright Stichting Eisdens Erfgoed (SEE), collection "inwoners cités Polen", not numbered.

the wall, she is its focus. It is unclear whether, like the dining room in the first photograph, this room was also used for other things. There is no direct evidence of a sofa, which might have indicated that the room was used both for eating and as a living room. At the level of the actors, the photograph is dominated by the woman, whom we know to be Polish. She is the only person in the room. She is wearing a black blouse under a white pinafore, an indication that she is occupied in a domestic activity. Her hair is neat and tidy; she is wearing earrings and a bracelet or watch on her left wrist and a ring on the ring finger of her left hand. In her other hand she is holding a small silver-coloured bowl with legs, a dish for serving potatoes or other vegetables. The woman is posed looking into the lens. Even so, she seems slightly surprised, or perhaps ill at ease.

It is largely the room in which the Polish woman is standing that makes this photograph so interesting, since it allows us to study the interior. The room too can be divided into three zones. The first is bottom left, where we see the table and two chairs. On the table is a decorative cloth, probably lace, on which we see a basket containing what might be dried or imitation decorative fruits (or perhaps the fruit is fresh). The second and most significant zone is the wall behind the sideboard and next to which the woman is standing. This decorated wall draws our attention. It is difficult to see whether it has been wallpapered or painted with the aid of a stencil. 
Since the top of the wall is edged with a decorative band, one suspects that it had been papered; where walls were papered (as in this dining room) it was commonplace in the mining community not to paper the top; this allowed the Regie (estate agency), which managed the buildings and houses on behalf of the mines, to save on the cost of wallpaper.

On the dark sideboard against the wall is an assortment of objects. We can see a framed photograph and a clock, and a number of what are probably small figurines. Here too the objects have been placed on lace cloths. In the centre of the wall hangs an imposing heavy frame containing a photograph of a woman, perhaps the woman in our photograph, or perhaps a close relative. The framed photograph is fairly artistic and completely dominates the wall. In the third zone we see a buffet/display cabinet, on which there are two objects, again placed on lace. As before, this is where the best tea service is displayed. The shelves are decorated, possibly with scalloped lace edging. The sizes and patterns of the lace edging vary, which might lead one to assume that the woman herself decorated the cabinet. One final element is the door to the far left of the room, leading into another room. We note the simple doorframe.

If we consider the photograph at the level of interpretation and meaning, we realize that the question of why it was taken is extremely important. We could assume that the Polish woman had recently married, and that the Regie in Eisden had just allocated the couple this house. The couple perhaps took this photograph to show off their new, recently furnished home. It is possible too, of course, that preparations are being made for a party; the room is tidy, everything is beautifully decorated, and the woman is preparing a meal. However, the photograph can also be interpreted as a scene of everyday life, or perhaps the family had just bought a new camera and simply wanted to try it out. So the question as to the photograph's purpose remains unresolved. Whatever the case, it still tells us a great deal about how a space was furnished and what objects were used in everyday life.

\section{CONCLUSION}

Comparing the two photographs is not a simple matter, of course, since the images give us access to two different garden cities, each with its own specific accent as regards people and residential forms, and because, of course, the nature of the photographs differ. Nonetheless, if we compare the two, we notice that the interior in the Eisden one is more highly decorated, with greater concern for detail, than the Beringen house, which on the whole leaves us with a sense of sobriety and respectability, certainly given that the Beringen photograph is taken from a promotional film. The familial situation varies too; in Beringen the emphasis is more on the family as a close-knit unit, while in Eisden the main focus is the woman in "her" 
interior or engaged in domestic work, a fact that reveals clues about the changing meaning of space in relation to the presence or otherwise of a member of a family. Regardless of whether the photograph is a personal image or taken from a promotional film, one thing is clear: women are shown as housewives who look after children or are occupied in domestic tasks (cf. the traditional male-female hierarchy).

The diligence and devotion that dominate both dining rooms is striking, but even more so in Eisden than in Beringen. See how, for instance, in the Eisden photograph the various objects are neatly placed on lace cloths. The way the image of the housewife is presented differs though, for in the Beringen photograph she is portrayed in matronly pose very much as the mother figure, while in the Eisden photograph it is not so much motherhood that is being emphasized as what is fashionable.

These two examples show that for the historian a comprehensive reading of photographic material offers an important or even essential source of information for the study of material culture and the everyday life of groups of workers, certainly when combined with additional background information on objects and types of clothing (for example, what type of wireless set is illustrated in the photograph and what significance does that have?). A series of photographs illustrating a certain type of garden city over a period of time, compiled for example on the basis of a typology and by working with image genres, enables us to see how the style of furnishing of miners' dwellings changed over time. One can say something too about the significance of the very fact that the photograph was taken.

These photographs reveal something about personal tastes and aspirations in what de Certeau calls everyday life. How did miners try to feel at home where they lived, and what importance did they attribute to privacy and the personal sphere? Was a "nice" interior important to them (ignoring for a moment the question of what they understood by "nice")? Did they design their interiors for themselves, or with an eye to conveying status or respectability, as we saw, for example, with the tea set and the plant? And did they have time for this? (Research has pointed to considerable intradistrict mobility, with around 700 moves each year in Eisden. $)^{34}$ Or did the fact that the houses were controlled by the mines play a role in one way or another? What significance did that have for the miners? What importance did they attribute to objects and spaces?

These questions can be answered by looking in meticulous detail at the objects, the wallpaper used, and the furniture; they also provide oblique references to the development of consumer society after World War II. These questions can be broadened to include the exterior material culture; the domestic interiors, but the urban vistas too and the views from the 
houses themselves are part of the study of everyday life. Questions about how the miners appropriated the imposed spaces of the garden city and what changes they in turn imposed on their spaces can be answered using plans, but also using photographs. 